\title{
Development of Urban Eco-Sustainable Index for Upscaling Water Security at Catchment Level in Langat River, Malaysia
}

\author{
Rahmah Elfithri' ${ }^{1}$, Mazlin Bin Mokhtar' ${ }^{1}$, Mohd Ekhwan Toriman², Marina \\ Zainal Abidin ${ }^{3}$ \& Fang Yenn Teo $^{4}$ \\ ${ }^{1}$ Institute for Environment and Development (LESTARI) \\ Universiti Kebangsaan Malaysia (UKM), Bangi, Selangor, Malaysia \\ ${ }^{2}$ Faculty of Social Science and Humanities (FSSK) \\ Universiti Kebangsaan Malaysia (UKM), Bangi, Selangor, Malaysia \\ ${ }^{3}$ Faculty of Science and Technology (FST) \\ Universiti Kebangsaan Malaysia (UKM), Bangi, Selangor, Malaysia \\ ${ }^{4}$ Faculty of Science and Engineering \\ University of Nottingham Malaysia (UNM), Semenyih, Selangor, Malaysia
}

Email: elfith@ukm.edu.my

\begin{abstract}
The Urban Eco-Sustainable Index for Upscaling Water Security at Catchment Level in Langat River, Malaysia has developed by using the Modified Watershed Sustainability Index or MicroWSI (MWSI), which was based on the Participation, Design and Management Components. The study has successfully applied spatial and social dimensions on ecohydrology of the selected Langat River reach for stormwater management, natural ecosystems health and quality of life. The planning and public participation aspects of the study have evaluated the surrounding neighborhood area of Langat. The conceptual design of rehabilitation works implementation related to Urban Stormwater Management Manual for Malaysia (MSMA) Stormwater Management Ecohydrology (SME) within the study area has been developed with four components of MSMA-SME to be implemented in the study area i.e Bioretention System, Porous Pavement System, Constructed Wetland and Slope Protection Works. These components were proposed to be applied in the development of Langat Riverfront Community Park (LRCP) which has taken into account the components of Design, Management and Participation of Community and Stakeholders in Langat River Basin, Malaysia. This study analyzed the MWSI for the Upscaling of MSMA Ecohydrology at Catchment Level of Langat River and has found the medium level of sustainability for the level of participation, proposed design, and management. Thus, there is a need to increase the level of readiness in the community and stakeholder participation in the Langat River towards sustainability of river conservation and rehabilitation programmes in this basin.
\end{abstract}

Keywords: Urban Eco-Sustainable Index, Watershed Sustainability Index, Ecohydrology, River Basin Management, Water security, Participation. 


\section{INTRODUCTION}

The Langat basin is currently faced with uncertainty. This includes political, economic and scientific uncertainties within which environmental policy decisions have to be made. The question is what is the most appropriate response? Environmental policy decisions are often made within the context of several uncertainties. The uncertainties might exist within the environment itself or within the processes of decision making themselves.

The study of a spatially integrated system, such as that of a river basin, is not an easy undertaking - especially for the purpose of management. There are many reasons why studies of such areas are mainly sectoral. One of the main reasons is the requirement of integrating the intricate components that make up the natural system is often too demanding to be achieved. Furthermore, considering that a team of researchers is a must in such a venture, the tools used to merge and synthesize the different information sections to create a whole must also be up to the task. While the management of the river basin is dependent upon the approach and the objectives set, the information base for the management must also be able to emulate the spatial relationship structure that make up the regional system.

Efforts to secure ecologically sound, efficient and socially effective resource utilization stand out as a major issue on the agenda for the 21 st century (FAO, 2000). Reduced per caput availability of water and other essential resources, coupled with an ongoing degradation of their quality, represents one of the most tangible threats to a continuing flow of the various goods and services required by society.

The "Upscaling of MSMA Stormwater Management Ecohydrology (MSMA-SME) at Catchment Level in Langat River" is a project that aims to provide a more appropriate stormwater management strategies and best practices and mitigation measures to counter negative effects of urbanization with the development of detailed design of various MSMA-SME components at Langat River Basin (LESTARI \& HTC 2015). The project has come up with plans to rehabilitate the heavily polluted and degradation of riverbank and slope erosion of Langat River for a long-term sustainable development within the river basin. The application of MSMA SME component into Langat River will be emerging and potentially can be as a transformative research idea to be implemented in the Langat River Basin.

MSMA components is one of the Best Managements Practices following IWRM approach and practices. With applying the MSMA components at Langat River catchment the untreated sewage and runoff water from a residential area will be treated through biofilter and Ecohydrology approach such as using biorentation, constructed wetland and porous pavement to improve the stormwater quality and quantity discharging into the urbanize Langat river. In Implementation, the eroded riverbank will be protected with a combination of environmental friendly products. Consequently with the application, it increase the awareness of local community and stakeholders on their role in an integrated river basin management action and project. It also contribute towards upscaling water security in Langat River Basin as well as for other river basins in Malaysia which are facing similar urbanised issues. By Upscaling Water Security at Catchment Level in Langat River, will provide solutions to the current global water challenges, which require upscaling of existing local 
approaches and knowledge of the interrelations between environment conditions and the state of waters (Khan, 2017).

The project has successfully applied spatial and social dimensions on eco-hydrology of the selected Langat River reach for stormwater management, natural ecosystems health and quality of life. With the proposed Langat Riverfront Community Park (LRCP) components, it is hope that this project will rehabilitate the riparian zone of the selected Langat River to improve recreational, tourism value, and strengthen the river basin management to ensure long-term sustainable development and pollution control. LRCP was designed and proposed to be developed in the Langat River as part of the Upscaling Water Security at Catchment Level in Langat River, Malaysia. The LRCP consists of Design component, Management component and Participation component. Overall, the idea of building the community park was to serve them outdoor recreation facilities and to engage them in local ecological governance.

\section{Design of Langat Riverfront Community Park}

Beyond storm water management to include efforts at local ecological governance \& public involvement for urban riverfront park creation. Incorporate with fitness facilities, children playground, main plaza, open plaza, trees, pedestrian/jogging track, and Langat River Information Centre. Serve the community outdoor recreation facilities \& local ecological governance.

\section{Management of Langat Riverfront Community Park}

Management component is important to establish sustainability of the project. Aspects taken into consideration are the readiness of policies and authoritative management to accept and support the project.

\section{Community and Stakeholder Participation of Langat Riverfront Community Park}

Community and related stakeholders are main key players in an integrated river basin management. The perception survey that has conducted for community and stakeholders in Langat River involving aspects of Proposed project location and rehabilitation components; Proposed Langat Riverfront Community Design; Proposed landscape and Langat Riverfront Community Park Facilities; Langat Riverfront Community Park Conservation Management; The local residents comment, views and opinion, has identified positive respons which showing community attitudes on the project operation and its benefit provided to the surrounding community. The result concluded that the surrounding community agreed on the design and the development of Langat Riverfront Community Park, and then willing to take part and ownership in the management and monitoring operation of the park. Other than giving sense of ownership to the surrounding community and stakeholders to ensure the sustainability and maintenance of the area, this also initiate and opportunity to get involvement from University student in many components. 


\section{URBAN ECO-SUSTAINABLE INDEX DEVELOPMENT}

Sustainable development needs knowledge of the interrelations between urban conditions and the state of waters as well as instruments and techniques for their management. Impacts on waters of sewage discharge, the high dynamics of storm water runoff, limited groundwater recharge, fragmentation, canalisation, culverting and others cause serious effects on aquatic organisms and the whole water ecosystems. In return they lead to manifold influences on urban life like e.g. decrease of water supply, risk to public health due to chemical and bacteriological water pollution, threats by flooding or loss of quality of urban open spaces by reduced aesthetic value. Aesthetic value also represents an important factor for the economic prosperity and social life in the basin.

Several issues impact the water sustainability of a river basin. Among them are the social, economic, and environmental aspects. However, they are often treated separately, and not as an integrated, dynamic process. In order to integrate the hydrologic, environmental, life and policy issues, as well as the existing pressures and policy responses in one quantitative, dynamic, and aggregated indicator, Chaves \& Alipaz (2007) introduce a watershed sustainability index (WSI) as an integrated indicator based on basin Hydrology, Environment, Life and Policy (HELP) state condition and uses a pressure-state-response function. The WSI studies have been done in some rivers basin under UNESCO-IHP HELP such as SF Verdadeiro, which have size around $2,200 \mathrm{~km}^{2}$ demonstration basin in Brazil. The WSI value obtained for this basin was 0.65 , which represents an intermediate level of basin sustainability.

The Langat River Basin has an area up to $2,400 \mathrm{~km}^{2}$, which is very suitable to apply the WSI study on this river basin. However the selected area of the Langat River Basin under this study is only covers an area up to $2 \mathrm{~km}$ long with a respective 20.6 $\mathrm{km}^{2}$ catchment area. Hence, the basic modified MicroWSI (MWSI) is proposed in this study.

The study on "Watershed Sustainability Index (WSI)" was conducted to analyse the environmental condition in the area incorporating ecological baseline and socioeconomic conditions. It was carried out in order to integrate the hydrologic, environmental, life and policy issues, as well as the existing pressures and policy responses in one quantitative, dynamic, and aggregated indicator. It includes gathering, describing and assessing relevant socio-economic data $\&$ with objective to conduct detail public participatory and urban social learning activities for WSI. To date some preliminary observations have been conducted, based on basin hydrology, environment, life and policy for the Langat River Basin.

The MWSI analysis is developed in this study through the integration of physical design and public participation from a coupled human-environment design approach that attempts to integrate sustainable physical design in the everyday life of the local neighbourhood. The conceptualization that have its beginning with Ian McHarg's Design with Nature (1969) is linked with Kevin Lynch's components of imageability (1960) as well as Shirvani's element of urban design (1985). Such conceptualization allow for a method that lends itself to the development of a neighborhood sustainability index as proposed by the study. 


\section{METHODOLOGY}

\subsection{Study Area}

The planning and public participation aspect of the study have begun to evaluate the surrounding neighborhood of Seksyen 3, Bandar Baru Bangi within the two kilometer stretch of Langat River in the context of the proposed MSMA-SME design and proposed riverine landscape design. The neighborhood comprise of home owners and renter occupants with public facilities that include playgrounds, a Mosque and schools on one side of the river, while the other comprise of small industries and repositories.

\subsection{Preliminary Data Collection}

The preliminary data have been collected and assessed, and it is estimated that this WSI study will be very useful in improving the current level of Langat River Basin i.e. from "Evolving" River Basin to become an "Operational" River Basin under the framework of UNESCO-IHP HELP Network. By using the HELP component for WSI analysis at catchment level the output of this study will be in line with the HELP objectives i.e. to deliver social, economic and environmental benefit to stakeholders through sustainable and appropriate use of water by directing hydrological science towards improved integrated catchment management basins and also implementation of research in collaboration between scientists, managers and stakeholders.

\subsection{Questionnaires Distribution}

The questionnaire was conducted to get local community view on the participation component, the proposed design of rehabilitation works implementation of MSMASME and LRCP, as well as the management component of the project site. Hence, The components of the questionnaire are divided as follow:

a. Community Participation or Willingness to be involved in the Conservation and Rehabilitation works at the project site.

b. Proposed project location, Proposed rehabilitation works components and Proposed Langat Riverfront Community Park Design.

c. Management of the Langat Riverfront Community Park.

During this study, structured-questionnaires were distributed to all respondents within the study area, mainly at Seksyen 3, Bandar Baru Bangi (Jalan 3/14 up to Jalan 3/70). The questionnaire prepared is in Bahasa Malaysia as to help the community to have better understanding on the proposed project. Overall, 133 questionnaires were received and assessed for the analysis of Micro Watershed Sustainability Index at Langat River Basin.

\subsection{Development of an 'Operational Level' of HELP WSI or MicroWSI}

The WSI analysis outlined a broader framework of analysing the sustainability index, while this study is in the process of developing a micro or site level WSI that put into consideration the potential of surrounding communities in participating and becoming 
the guardian of the specific projects proposed. The micro sustainability index will include the participatory component derived from a Rapid Participatory Analysis (RPA) to be conducted in the surrrounding area, a design component that evaluates the potential embeddedness of the MSMA projects with respect to the surrounding environment and communities, and a management component that takes into consideration the readiness of policies and authoritative management to accept and support the MSMA projects. Thus, the basic modified MicroWSI used in this study based on the Participation Component (P), Design Component (D) and Management Component (M) following Figure 3.1.

\section{$M W S I=P+D+M$}

Figure 3.1: Proposed modified MicroWSI

The scale in MWSI was classified by the level of readiness or level of importance towards any proposed initiatives or components in this study. Hence, highest scale is represented by the answer "very important or very willing", while medium scale is represented by the answer "important or ready". The lowest scale is represented by the answer "not important/very not important or not ready/very not ready" or when there is no answer indicating that the respondents might not understand the question.

For the Participation Component, Highest Level referred to the community and stakeholder readiness and willingness to participate in the conservation and rehabilitation works of the Langat River and particularly the Langat Riverfront Community Park (LRCP); Medium Level referred to partly involvement in the conservation and rehabilitation works; while Lowest Level referred to unwillingness or not ready to be involved in the conservation and rehabilitation works of LRCP.

For the Design Component, Highest Level referred to their agreement or approval on the proposed design of MSMA-SME and LRCP; Medium Level referred to partly agreed or approved on the proposed design and some improvements needed to be done; while Lowest Level referred to disagreement or unpleasant with the proposed design.

For the Management Component, Highest Level referred to involvement in the main structure and directly in the project (project planning and study site), field work, questionnaire, and stakeholder consultation workshop; Medium Level referred to involvement in project meetings or programmes organized by the researchers; and Lowest Level referred to involvement in interactions regarding "Upscaling of MSMA Eco-Hydrology at catchment level (Langat River) project implementation. 


\section{RESULTS AND DISCUSSION}

\subsection{Preliminary Issues and Impacts on Hydrology for the Environment, Life and Policy (HELP) in Langat River}

The study has started the ground trothing for the area as well as setting up the sampling frame needed for the study. Apart from the neighborhood survey, respondents for the proposed focus group discussion are also being determined. Preliminary observations in the area suggest the need to tackle several spatial and physical obstacles that hamper community use of the facilities proposed.

\section{Hydrological and Water Management Issues}

It is found that some issues related to Hydrological and Water Management at the study area are as below:

- The amount of water abstracted can be drastically reduced at times due to droughts and excessive pollution of the river

- Improper management of industries and domestic effluent discharges

- Some forest clearing and lack of proper land management

- Flooding and water rationing at certain times

- The shortage of water supply

- To ensure a reliable supply of quality water for domestic purposes

This study has also observed some impacts related to Water and Climate in the study area as follow:

- Draught and wet periods such as those triggered by El Nino and La Nina has had enormous impact on the river.

- Flood or shortage of water supply becomes a major issue whenever there are unpredictable changes in climate.

- The prolongued drought has brought the problems of water imbalance caused by high water demand and low water supply.

- Flooding can happen due to heavy 7 rothing $7 \mathrm{t}$ are influenced by climate of equatorial zone in Malaysia.

\section{Environmental Issues}

It is found that some issues related to the Environment at the study area are as below:

- Indiscriminate discharge of industry effluent

- Domestic sewage from urban centers

- Poor land management practices along the river basin

- River water quality deterioration

- Mining operations

- Housing and road development

- Logging

- Clearing of forests

- Inadequate management of solid waste

- Discharge of untreated waste water 
This study has also observed some impacts related to Water and Environment in the study area as follow:

- Damage in the river will cause the loss of habitats for fauna and flora conservation and also recreational facilities for the people.

- Population growth and rapid development in the Langat Basin can cause:

- Rapid changes in land use patterns

- Increase pressure on natural and environmental resources

- Lead to higher incidences of social ills associated with high density urban living

\section{Livelihoods Issues}

It is found that some issues related to the Livelihoods at the study area are as below:

- Poor water management during draught or due to river pollution has caused some misery to the livelihood of people in the Langat Basin, and could affect businesses and shops that depend on clean water supply.

- Further deterioration in water quality is also affecting the aquaculture industry near the estuary of the Langat River.

- Poor water quality causes poor harvest of aquaculture produce and loses in income.

Some impacts of the issues related to Water for Food are described below:

- Improve in water quality of the Langat River will certainly protect the aquaculture food produce such as shrimps and fish from undesirable contaminants.

- The quality and quantity of the seafood produced from the Basin depend heavily on the water quality.

- A good irrigation and drainage system in agricultural area will increase the productivity of crops every year.

Some Impact of the Issues related to Water Quality and Human Health are also outlined as follow:

- The health of the population is closely related to the river water quality.

- The presence of heavy metals, chlorinated hydrocarbons and pathogens have long and short term impacts on public health.

- The water borne diseases that affects human health and destroyed aquatic lives and habitats.

- The quality of life of the human and other living beings for the long term is under threat.

\section{Policy and Legislation Issues}

It is found that some issues related to the Policy and Legislation at the study area are as below:

- There is currently no one Federal or National Body with all rights to deal with water resource management throughtout the whole country.

- There is no uniform set of rules or regulations imposed on all states.

- There is not a body vested with a natural monopoly over the supply of water. 
- There is an abundance of sectoral based water laws at both Federal and state levels, but they lack comprehensiveness and integration in these laws.

- There are overlaps and gaps in existing legislation at both the federal and state levels.

- There are also overlaps and gaps in the enforcements, particularly as there are a number of agencies involved.

- There are a number of Local Authorities working independently within each river basin, each having ist own needs and political influence.

Above issues give impacts related to Water and Conflict as highlighted below:

- The consumer demands of high quality and uninterrupted water supply but there is inadequate control of effluent discharge from industries and urban centers to avoid water pollution.

- The development in the Basin cannot be halted just to protect the river resource as people also needs development to improve their quality of life.

- The stakeholders in Langat Basin are trying to focus in a particular specific area, which could cause a conflict among other types of water use.

\subsection{Constructing the Human-Environment Interface of the MSMA Upscaling Effort}

This section presents the human-environment interface of the proposed project. It highlights the general approach as well as an update of work done on this section. It applies several ideas on green design as proposed by Barton (1997) to ensure the best linkage to be provided by the project. These include:

1. Increasing Local self-sufficiency. This principle approaches the township as an ecosystem, which provide the essential local habitat with its own microclimate. Designers will attempt to 9rothing the level of autonomy of the ecosystem.

2. Human Needs. Social and environmental goals should be mutually re-inforcing and the starting point for a green design should be the satisfaction of basic human needs of shelter, warmth, health, opportunities for work, access to facilities and a pleasant environment.

3. The Open Space Network. The emphasis here is towards the linking of open space for interrelated purposes including energy, wildlife, water and pollution management.

4. An Energy Strategy. Reduction of heat loss, maximizing solar gain, and combinations of heat and power stations are among the main concerns of this principle, although in tropical townships, heat loss is not an important factor.

5. Water Strategy. Strategy to control water run-off and the quality of water with respect to increasing development.

Community based design is the essence for future drainage basins. A communitybased design has as its primary focus the development, growth or stability of the social structure underlying the system instead of a concern for physical additions. 
The design does not see the people as merely numbers to fulfill some planning standards but rather as a complex interweaving network of living and vibrant communities. Thus the planning begins with identifying these social forces. These include the identification of neighbourhoods and other social nodes. From these nodes, grassroot activities that permeate the foundations of the communities are kept alive and even promoted.

Second, the physical environment of these communities are identified and maintained. The physical environment is defined as the nexus for social and sacred space and is developed as such. Where lacking, careful interventions are done to ensure organic growth. Even if the design follows Lynch's classical demarcations, much can be achieved. A careful study of the environmental lattice that ties the different cultural events allow for a better understanding of how man's interaction with the environment takes place.

The idea of a spatially integrated design proposed in this research is much more than simply setting up roads and other access to the different areas. One of its main concern is to integrate the physical and human activities components of the river basin. With different group of residents come different needs - both physical and social.

\subsection{MWSI Analysis}

Micro Watershed Sustainability Index (MWSI) was obtained by classifying the level of readiness or level of importance felt by community towards any proposed initiatives, design or components prepared in three aspects of participation, design and management. The respondent's responses were classified into Highest Level $(\mathrm{H})$, Medium Level (M) and Lowest Level (L) of Participation, Design and Management. In this study the total respondents of the questionnaire were 133, and the questions or related components were classified into 24 criteria each.

\subsubsection{Participation Component (P)}

Community and stakeholder participation in river conservation is very important and plays crucial role in sustaining the health of river ecosystem (Megdal et al, 2017). It needs to be created and motivated in order to get people involved and jointly work together in the conservation and management of the river. The Participation Component under this study was assessed through structured-questionnaires that were distributed to all respondents within the study area as shown in Table 4.1.

Table 4.1: Participation Components

\begin{tabular}{|l|l|c|c|c|}
\hline No. & \multicolumn{1}{|c|}{ Question } & H & M & L \\
\hline P1 & $\begin{array}{l}\text { I am interested to know more about } \\
\text { Langat River and Conservation of } \\
\text { the Ecosystem }\end{array}$ & 56 & 66 & 27 \\
\hline P2 & $\begin{array}{l}\text { I am interested to plant herbaceous } \\
\text { plants in the region and will } \\
\text { maintain these plants }\end{array}$ & 33 & 73 & \\
\hline
\end{tabular}




\begin{tabular}{|c|c|c|c|c|}
\hline P3 & $\begin{array}{l}\text { Langat Riverfront Community Park } \\
\text { is jointly owned and I'm willing to } \\
\text { keep the cleanliness and beauty of } \\
\text { Langat Riverfront Community Park } \\
\text { although without pay }\end{array}$ & 58 & 63 & 12 \\
\hline P4 & $\begin{array}{l}\text { I am willing to spend a little expense } \\
\text { when necessary for conservation of } \\
\text { Langat } \quad \text { Riverfront Community } \\
\text { Park. }\end{array}$ & 33 & 69 & 31 \\
\hline P5 & $\begin{array}{l}\text { I will ensure that no rubbish is } \\
\text { produced in the area of the park to } \\
\text { be developed. }\end{array}$ & 62 & 61 & 10 \\
\hline P6 & $\begin{array}{l}\text { People living in the upstream area of } \\
\text { Langat River have to participate in } \\
\text { order to maintain the cleanliness of } \\
\text { the Langat River downstream side }\end{array}$ & 87 & 39 & 7 \\
\hline P7 & $\begin{array}{l}\text { Acknowledgement or reward should } \\
\text { be given to the people living in the } \\
\text { upstream area of Langat River who } \\
\text { actively keeping the river clean so } \\
\text { that they always maintain the } \\
\text { cleanliness and encouraged not to } \\
\text { pollute the river. }\end{array}$ & 66 & 53 & 14 \\
\hline \multicolumn{5}{|c|}{ Frequency participating neighborhood activities } \\
\hline P8 & Communal work & 31 & 92 & 10 \\
\hline P9 & Weddings & 39 & 86 & 8 \\
\hline $\mathrm{P} 10$ & Religious activities & 41 & 85 & 7 \\
\hline P11 & Visiting ill neighbour & 37 & 83 & 13 \\
\hline P12 & Visiting neighbours & 27 & 96 & 10 \\
\hline P13 & Political related activities & 5 & 36 & 92 \\
\hline P14 & Entertainment/feast & 8 & 71 & 54 \\
\hline P15 & Association/club meeting & 23 & 78 & 32 \\
\hline \multicolumn{5}{|c|}{ Frequency of activities done at parks or green open areas } \\
\hline $\mathrm{P} 16$ & Light recreational activity (alone) & 23 & 81 & 29 \\
\hline P17 & $\begin{array}{l}\text { Light recreational activity (with } \\
\text { family) }\end{array}$ & 38 & 90 & 5 \\
\hline P18 & $\begin{array}{l}\text { Light recreational activity (with } \\
\text { friends) }\end{array}$ & 31 & 82 & 20 \\
\hline P19 & Social activities with family & 44 & 83 & 6 \\
\hline $\mathrm{P} 20$ & Social activities with public & 10 & 43 & 80 \\
\hline P21 & Political related activities & 4 & 29 & 100 \\
\hline $\mathrm{P} 22$ & Entertainment/feast & 5 & 66 & 62 \\
\hline $\mathrm{P} 23$ & Association/club meeting & 14 & 78 & 41 \\
\hline P24 & $\begin{array}{l}\text { If given the chance, would you want } \\
\text { to be involved in the management } \\
\text { and care of the park? }\end{array}$ & 120 & 2 & 11 \\
\hline & TOTAL & 895 & 1605 & 692 \\
\hline
\end{tabular}




\subsubsection{Design Component (D)}

Design and Landscaping of the river is part of the regeneration of the river. The Design component of MSMA project involves Bioretention System, Porous Pavement System, Constructed Wetland and Slope Protection. While the landscaping component of LRCP involves Main Entrance, Langat River Information Centre, Constructed Wetland, Pedestrian/Jogging Track, Trees, Children Playground and Fitness Facilities. The Design Component analysis under this study was obtained through questionnaires that were distributed to all respondents within the study area to identify the suitability of the proposed construction site and rehabilitation components as shown in Table 4.2.

Table 4.2: Design Components

\begin{tabular}{|c|c|c|c|c|}
\hline NO & Criteria & $\mathbf{H}$ & $\mathbf{M}$ & $\mathbf{L}$ \\
\hline D1 & $\begin{array}{l}\text { Location Nearby UKM and Taman } \\
\text { Tasik Bangi, Section } 3\end{array}$ & 43 & 83 & 7 \\
\hline $\mathrm{D} 2$ & $\begin{array}{l}\text { Construction of Wetlands for water } \\
\text { quality recovering through natural } \\
\text { filtration series }\end{array}$ & 83 & 47 & 3 \\
\hline D3 & $\begin{array}{l}\text { Bioretention system to filter } \\
\text { rainwater and reduce the speed of } \\
\text { rainwater fall from slope to Sungai } \\
\text { Langat }\end{array}$ & 79 & 53 & 1 \\
\hline $\mathrm{D} 4$ & $\begin{array}{l}\text { Construction of porous pavement } \\
\text { and used as walkways or parking } \\
\text { that allows rainwater to be absorbed } \\
\text { by the surface and flowed into the } \\
\text { ground }\end{array}$ & 65 & 64 & 4 \\
\hline D5 & $\begin{array}{l}\text { Slope protection is a component of } \\
\text { restoration and slope stabilization } \\
\text { using natural elements such as } \\
\text { geotextile to prevent erosion }\end{array}$ & 87 & 45 & 1 \\
\hline \multicolumn{5}{|c|}{ Proposed Langat Riverfront Community Park Design } \\
\hline D6 & Main Entrance & 57 & 70 & 6 \\
\hline D7 & Route to Main Plaza & 49 & 66 & 18 \\
\hline D8 & Main plaza & 53 & 66 & 14 \\
\hline D9 & Langat River Information Center & 64 & 57 & 12 \\
\hline D10 & Bridge & 63 & 59 & 11 \\
\hline D11 & Open plaza & 55 & 66 & 12 \\
\hline D12 & Overall Proposed Park Design & 58 & 57 & 18 \\
\hline D13 & Trees & 100 & 33 & 0 \\
\hline D14 & Herbaceous Plants & 62 & 60 & 11 \\
\hline D15 & Playground & 58 & 59 & 16 \\
\hline D16 & Fitness Equipment & 58 & 65 & 10 \\
\hline D17 & Concrete Bollard & 32 & 53 & 48 \\
\hline D18 & Jogging Track & 73 & 56 & 4 \\
\hline D19 & Reflexology Path & 59 & 57 & 17 \\
\hline
\end{tabular}




\begin{tabular}{|l|l|c|c|c|}
\hline D20 & Rubbish Bin & 112 & 20 & 1 \\
\hline D21 & Park Benches & 83 & 48 & 2 \\
\hline D22 & $\begin{array}{l}\text { Parking Lot Inside Langat } \\
\text { Riverfront Community Park }\end{array}$ & 57 & 47 & 29 \\
\hline D23 & $\begin{array}{l}\text { Parking Lot Outside Langat } \\
\text { Riverfront Community Park to } \\
\text { reduce air pollution }\end{array}$ & 87 & 44 & 2 \\
\hline D24 & $\begin{array}{l}\text { Overall Proposed Landscape and } \\
\text { Park Facilities }\end{array}$ & 72 & 48 & 13 \\
\hline TOTAL & $\mathbf{1 6 0 9}$ & $\mathbf{1 3 2 3}$ & $\mathbf{2 6 0}$ \\
\hline
\end{tabular}

\subsubsection{Management Component (M)}

For management component, the stakeholders considered involved in the highest stage of management are those who involved directly in the main structure for the project planning either the consultants or community. As for the medium stage of management, this will include those who involved in the meetings or programmes related to "Upscaling of MSMA Ecohydrology at Catchment Level (Sg. Langat)". While the lowest stage of management were referred to any form of interactions regarding the project. It also included interactions during programmes that were held regarding the project as shown in Table 4.3.

Table 4.3: Management Components

\begin{tabular}{|c|c|c|c|c|}
\hline NO & Type of Management & H & $\mathbf{M}$ & $\mathbf{L}$ \\
\hline M1 & $\begin{array}{l}\text { Stakeholder responsible for the } \\
\text { rehabilitation and the Management of } \\
\text { LRCP (Federal Government) }\end{array}$ & 56 & 77 & 0 \\
\hline M2 & $\begin{array}{l}\text { Stakeholder responsible for the } \\
\text { rehabilitation and the Management of } \\
\text { LRCP (State Government) }\end{array}$ & 91 & 42 & 0 \\
\hline M3 & $\begin{array}{l}\text { Stakeholder responsible for the } \\
\text { rehabilitation and the Management of } \\
\text { LRCP (Local Authority/Kajang } \\
\text { Municipal Council) }\end{array}$ & 108 & 25 & 0 \\
\hline M4 & $\begin{array}{l}\text { Stakeholder responsible for the } \\
\text { rehabilitation and the Management of } \\
\text { LRCP } \\
\text { organization (NGO) }\end{array}$ & 55 & 78 & 0 \\
\hline M5 & $\begin{array}{l}\text { Stakeholder responsible for the } \\
\text { rehabilitation and the Management of } \\
\text { LRCP (Private Sector) }\end{array}$ & 50 & 83 & 0 \\
\hline M6 & $\begin{array}{l}\text { Stakeholder responsible for the } \\
\text { rehabilitation and the Management of } \\
\text { LRCP (University) }\end{array}$ & 65 & 68 & 0 \\
\hline M7 & $\begin{array}{l}\text { Stakeholder responsible for the } \\
\text { rehabilitation and the Management of } \\
\text { LRCP (Individual) }\end{array}$ & 75 & 58 & 0 \\
\hline
\end{tabular}




\begin{tabular}{|c|c|c|c|c|}
\hline M8 & $\begin{array}{l}\text { Stakeholder responsible for the } \\
\text { rehabilitation and the Management of } \\
\text { LRCP (Resident's Association) }\end{array}$ & 71 & 62 & 0 \\
\hline M9 & $\begin{array}{l}\text { Stakeholder responsible for the } \\
\text { conservation management of Langat } \\
\text { River Information Center (Federal } \\
\text { Government/DID Malaysia) }\end{array}$ & 79 & 54 & 0 \\
\hline M10 & $\begin{array}{l}\text { Stakeholder responsible for the } \\
\text { conservation management of Langat } \\
\text { River Information Center State } \\
\text { Government/DID Selangor) }\end{array}$ & 96 & 37 & 0 \\
\hline M11 & $\begin{array}{l}\text { Stakeholder responsible for the } \\
\text { conservation management of Langat } \\
\text { River Information Center (University } \\
\text { Kebangsaan Malaysia (UKM) }\end{array}$ & 65 & 68 & 0 \\
\hline M12 & $\begin{array}{l}\text { Stakeholder responsible for the } \\
\text { conservation management of Langat } \\
\text { River Information Center } \\
\text { (Community Section 3, Bandar Baru } \\
\text { Bangi Neighborhood Association) }\end{array}$ & 60 & 73 & 0 \\
\hline M13 & $\begin{array}{l}\text { Involvement in the main structure of } \\
\text { LRCP and/or directly in the project } \\
\text { (project planning and study site) }\end{array}$ & 15 & 10 & 108 \\
\hline M14 & $\begin{array}{l}\text { Involvement during project field } \\
\text { work (land surveyor and landscape } \\
\text { architect) }\end{array}$ & 10 & 10 & 113 \\
\hline M15 & $\begin{array}{l}\text { Involvement during Stakeholder } \\
\text { Consultation Workshop on Langat } \\
\text { Riverfront Community Park (Bangi } \\
\text { 3, Bangi Perdana, Taman Tasik } \\
\text { Bangi 3, Damai Impian, Surau Al } \\
\text { Radhah, ZHL UKM) }\end{array}$ & 25 & 10 & 98 \\
\hline M16 & $\begin{array}{l}\text { Involvement in filling up } \\
\text { questionnaire (Bangi 3, Bangi } \\
\text { Perdana, Taman Tasik Bangi 3, } \\
\text { Damai Impian, Surau Al Radhah) }\end{array}$ & 100 & 33 & 0 \\
\hline M17 & $\begin{array}{l}\text { Involvement in IWRM } \\
\text { Workshop (Perbadanan Putrajaya } \\
\text { PPj, Kajang Municipal Council } \\
\text { (MPKj), UKM }\end{array}$ & 20 & 10 & 103 \\
\hline M18 & $\begin{array}{l}\text { Involvement in Water Information } \\
\text { access Carnival (Perbadanan } \\
\text { Putrajaya (PPJ), Lembaga Urus Air } \\
\text { Selangor (LUAS), Konsortium } \\
\text { ABASS Sdn Bhd (ABASS), Indah } \\
\text { Water Consortium (IWK), } \\
\text { Sustainable Resource Intensification } \\
\text { Malaysian Agroecology Society } \\
\text { (SRI-Mas), Zero Waste Campus } \\
\text { Initiative, (Kolej Ibu Zain, }\end{array}$ & 70 & 11 & 52 \\
\hline
\end{tabular}




\begin{tabular}{|c|c|c|c|c|}
\hline & $\begin{array}{l}\text { EKORELAWAN UKM, Kajang } \\
\text { Municipal Council (MPKj), Section } \\
7 \text { Bandar Baru Bangi Residential } \\
\text { Association, LESTARI) }\end{array}$ & & & \\
\hline M19 & $\begin{array}{l}\text { Involvement during Water Conflict } \\
\text { in Mega Urban Region Ecosystem } \\
\text { (GEC, PPj, UKM, Universiti } \\
\text { Teknologi Malaysia } \\
\text { Community }\end{array}$ & 20 & 5 & 108 \\
\hline M20 & $\begin{array}{l}\text { Involvement in Malaysian Water } \\
\text { Resources Management (MyWRM) } \\
\text { Forum: Academy of Sciences } \\
\text { Malaysia (ASM), RPM Engineers } \\
\text { Sdn. Bhd., National Hydraulic } \\
\text { Research Institute Malaysia } \\
\text { (NAHRIM), MyWP, UKM }\end{array}$ & 15 & 10 & 108 \\
\hline M21 & $\begin{array}{l}\text { Involvement in UNESCO Day } \\
\text { exhibition (Kelab Seni Lukis Daerah } \\
\text { Hulu Langat, Warisan Geologi } \\
\text { Malaysia, Jabatan Warisan Negara, } \\
\text { UNESCO-IHP Malaysia, SKUM, } \\
\text { HTC-KL, UKM) }\end{array}$ & 30 & 10 & 93 \\
\hline M22 & $\begin{array}{l}\text { Involvement during national forum } \\
\text { on sustainability science on river } \\
\text { basin management (DID, IWK, } \\
\text { LUAS, SRI-Mas, CETDEM, UKM) }\end{array}$ & 15 & 10 & 108 \\
\hline M23 & $\begin{array}{l}\text { Involvement in World Water Day } \\
\text { Celebration (PPj, UKM, DID, } \\
\text { Community) }\end{array}$ & 30 & 10 & 93 \\
\hline M24 & $\begin{array}{l}\text { Involvement in Result and Report } \\
\text { refining workshop (UKM) }\end{array}$ & 10 & 5 & 118 \\
\hline & TOTAL & 1231 & 859 & 1102 \\
\hline
\end{tabular}

\subsubsection{Micro Watershed Sustainability Index}

The Micro Watershed Sustainability Index (MWSI) was analyzed by using the Modified MicroWSI formula, where MWSI $=\mathrm{P}+\mathrm{D}+\mathrm{M}$. Hence, based on the cumulative total of Participation Component, Design Component and Management Component shown in the above tables, the total of Highest Level, Medium Level and Lowest Level of Participation Component, Design Component and Management Component were summarized in Table 4.4 below: 
Table 4.4: Summary of Participation, Design and Management Components for Langat River Conservation Park

\begin{tabular}{|l|c|c|c|c|c|c|}
\hline \multirow{2}{*}{ MWSI } & \multicolumn{2}{|c|}{ Highest } & \multicolumn{2}{c|}{ Medium } & \multicolumn{2}{c|}{ Lowest } \\
\cline { 2 - 7 } & Score & Respondent & Score & Respondent & Score & Respondent \\
\hline Participation (P) & 895 & 37 & $\mathbf{1 6 0 5}$ & $\mathbf{6 7}$ & 692 & 29 \\
\hline Design (D) & $\mathbf{1 6 0 9}$ & $\mathbf{6 7}$ & 1323 & 55 & 260 & 11 \\
\hline Management (M) & $\mathbf{1 2 3 1}$ & $\mathbf{5 1}$ & 859 & 36 & 1102 & 46 \\
\hline TOTAL & $\mathbf{3 7 3 5}$ & $\mathbf{1 5 5}$ & $\mathbf{3 7 8 7}$ & $\mathbf{1 5 8}$ & $\mathbf{2 0 5 4}$ & $\mathbf{8 6}$ \\
\hline
\end{tabular}

Note:

Score: The total responses received from the respondents

Respondent: Average Respondents who gave response = Total Score/24 (Total Questions for each Components)

The table clearly shown that the overall results of MWSI at the project site or 'Operational Level' of HELP WSI was at the Medium Level of Sustainability (with the total score of Medium MWSI = 3787). This indicates that, the community agreed that they have medium level of approval and agreement on Participation, Design and Management aspects, although the overall results were actually shown that they have medium level of readiness in the participation aspect (i.e. 1605), while for the Design Component and Management Component the community were actually shown strong or high level of agreements (i.e. 1609 and 1231), which means they felt that the Design and Management Components of LRCP have already in such a good quality of design and management, however the Participation Component such as the community and stakeholders involvement in conservation and rehabilitation of Langat River need to be further enhanced and improved in the future. Moreover, the community of the Section 3 Bandar Baru Bangi has to be engaged further in the project planning to create sustainable local ecological governance. 


\section{CONCLUSION AND RECOMMENDATION}

The WSI analysis using the HELP components (based on basin hydrology, environment, life and policy) is the first study conducted in Malaysia as well as in the Langat River Basin area to match with the UNESCO-IHP HELP needs and following the initiative that have been taken initially by other river basin in the world that have been implemented this approach previously, especially the application of the modified MicroWSI as an urban Eco-Sustainable Index for Upscaling Water Security at Catchment Level in Langat River, Malaysia.

The study found that the Upscaling of MSMA Ecohydrology at Catchment Level (Sg.Langat) has medium level of sustainability for the level of participation, proposed design, and management. It means a lot more efforts need to be done towards sustainability of this project as part of the bigger Langat River Basin. Langat River Basin is not one ecosystem but many. From a coastal ecosystem to the west, there is a complexity of ecosystems that finally turned into a highland environment to the west. In between are mangroves, riverine, urban and lowland forest ecosystems. These ecosystems are also at different stages and levels of sensitivity. No one can plan solution that is appropriate for the entire basin. Thus different strategies and approach are needed.

Overall, the study has successfully studied and developed urban eco-sustainable index for the residents within the study area that is MicroWatershed Sustainability Index (MSWI). This study has also identified the public participatory and urban social learning activities for WSI of Langat River Basin and evaluated public opinion based on locals views on the Langat Basin. Knowledge sharing on developing MWSI also can be beneficial for relevant authorities on water or river basin management. 


\section{ACKNOWLEDGEMENT}

The authors would like to express appreciation to Institute for Environment and Development (LESTARI), Universiti Kebangsaan Malaysia (UKM) with the collaboration of Department of Irrigation and Drainage (DID), Humid Tropics Centre Kuala Lumpur (HTCKL), UNESCO Office Jakarta, and also Malaysian Funds-inTrust (MFIT) for the financial supports in the implementation of this project on Upscaling of MSMA Ecohydrology at Catchment Level (Langat River). Appreciation is also extended to Integrated Water Resource Management (IWRM) Research Group of UKM and Project Team Members who are involved directly or indirectly in conducting this project. The study is supported by research grant of UKM through XX-15-2012, XX-2015-006, XX-2015-008 and XX-2016-001.

\section{REFERENCES}

Barton, L. 1997. Inclusive Education: Romantic, Subversive or Realistic. Int. J. Inclusive Education. Vol. 1, No 3, 231-242.

Chaves HML \& Alipaz S (2007), An Integrated Indicator for Basin Hydrology, Environment, Life, and Policy: The Watershed Sustain-ability Index. Water Resources Management 21, 883-895

FAO. 2000. New Dimensions in Water Security - Water, society and ecosystem services in the 21 st century. Food and Agriculture Organization of the United Nations. Rome, Italy. (http://www.fao.org/3/a-x4687e.pdf).

Khan, S. Upscaling Water Security to Meet Local, Regional, and Global Challenges: Project Results. 2017. UNESCO. (http://mucp-mfit.org/wpcontent/uploads/D1_Keynote-Shahbaz-Khan-Upscaling-Water-Security.pdf)

LESTARI \& HTC. 2015. Upscaling of the MSMA Stormwater Ecohydrology at Catchment Level in Langat River. Institute for Environment and Development (LESTARI), Universiti Kebangsaan Malaysia, Bangi, Selangor, Malaysia.

Lynch, K. 1960. The Image of the City. The MIT Press. Cambridge.

McHarg, I. 1969. Design With Nature. John Wiley \& Sons.

Megdal, S. B., Eden, S., \& Shamir, E. 2017. Water Governance, Stakeholder Engagement, and Sustainable Water Resources Management. Water 2017, 9, 190.

Shirvani, H. 1985. The Urban Design Process. Van Nostrand Reinhold Company. 